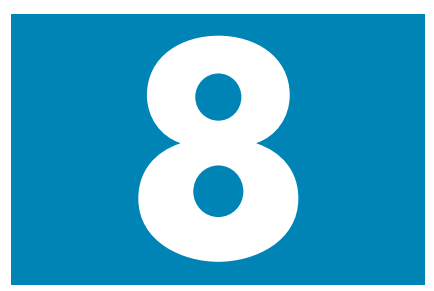

\title{
The training plan
}

\author{
M. Grace ${ }^{\prime}$
}

\section{A training plan needs to be a working document that helps ensure the appropriate training for everyone in the organization is carried out.}

${ }^{1}$ Editor, British Dental Journal, 64 Wimpole Street, London W1 G 8YS

${ }^{*}$ Correspondence to: Mike Grace email:m.grace.bdj@bda-dentistry.org.uk REFEREED PAPER

() British Dental Journal

2001; 191: 181-184
$\mathrm{H}$ aving considered the different learning styles and the factors involved in learning, we are now ready to seriously consider how to draw up a training plan.

Planning, like most things that involve creative thought, is often avoided or at best skimped. The essence of Investors in People is the training plan, preferably written down, yet so often people avoid the production of a training plan because they feel they either know the training required (it is obvious) or they argue it is impossible to plan accurately because there is no guarantee there will be a course available at the time.

Neither of these excuses is valid. There is a great difference between being aware of a training need and providing the training, and organisations without a plan often find they reach the end of 12 months without carrying out the 'obvious' training because everyone is so busy and somehow the training was forgotten. The argument about not knowing if a course is available at the time you have it written in your training plan falls down for two reasons. Firstly the training might not be a course anyway, as there are a number of alternative methods of training (see Part 7). Secondly, even if a course is appropriate, the exact date is less relevant than the fact we know that the training is required. Having a written plan makes it more likely we will identify a course because we know it is written in the plan. If it happens to be a month or two early or late is hardly a reason for not planning at all.

\section{The basics of a training plan}

A training plan needs to be a working document that helps ensure the appropriate training for everyone in the organization is carried out.

There are certain basic aspects to an effective training plan:

- It should contain the names of all the people in the organization

- It should list the subject areas where training needs have been identified

- It should contain dates for the proposed training

- It should list the direct costs of training (where applicable)

- It should link the training to a business objective

Additional topics in a training plan could also be:
- It could link the training to a training objective

- It could suggest the method of training

- It could include evaluation of the training

An ideal training plan would contain all the above points, but certain organizations (possibly smaller ones) might choose to leave some of the suggested areas out. The more topics the training plan includes - the more effective it is likely to be. Figure 1 shows a possible template for a training plan that includes all the points mentioned above.

We can consider each topic in more detail.

\section{Names of people}

At first sight this might seem obvious. However some training plans fail to list people individually and will simply include 'the receptionists' or 'the dentists'. This is not only less specific, but removes the feeling in people that they are important and count, because individual training has not been organized for them as specific people.

The argument for leaving names out of the plan is that people may leave the organization and thus it is a waste of time putting the names in. This is so weak it is hardly worth pointing out that the plan can be changed and the new name added, but also fails to recognise that when people leave and new people are recruited then a new training needs analysis is required to identify the needs of the new person joining the organization.

We must also remember that everyone is an individual with different learning styles, and thus different methods of training may be required for different people.

\section{Subject areas and dates}

In Part 6 we saw how the analysis of the data gathered in a TNA will end up with a list of topics where gaps in knowledge and skills have been identified (Fig. 2). These obviously form the basis for the topics that can be written down in the training plan opposite the relevant people.

In this scenario we are looking at two individuals in a dental practice, Caroline Draymore (an associate) and Claire Holbrook (the practice manager). Their training needs have been identified as outlined in Figure 2, but we now need to consider the priorities. Both of them have quite a number of areas where training is needed, so which are more important? 


\section{Fig. I Template for a training plan}

\section{PRACTICE TRAINING PLAN}

\begin{tabular}{|l|l|l|l|l|l|l|l|}
\hline Name & $\begin{array}{l}\text { Training } \\
\text { activity }\end{array}$ & Date & Cost & $\begin{array}{l}\text { Training } \\
\text { objective/desired } \\
\text { outcome }\end{array}$ & $\begin{array}{l}\text { Link with business } \\
\text { objective }\end{array}$ & $\begin{array}{l}\text { Outcome/ } \\
\text { evaluation }\end{array}$ & $\begin{array}{l}\text { Further action } \\
\text { needed? }\end{array}$ \\
\hline & & & & & & & \\
\hline & & & & & & & \\
\hline
\end{tabular}

\section{Fig. 2 Some current gaps in knowledge and skills} identified in the TNA

\section{Current Training Needs Analysis}

\section{Caroline Draymore (associate dentist)}

Clinical

Periodontal monitoring

Root planing

\section{Management}

Strategic forecasting

Decision-making

Time management

\section{Marketing \\ Customer care \\ Selling ethically}

\section{Claire Holbrook (practice manager)}

\section{Management \\ Recruitment and selection \\ Interviewing \\ Running effective meetings}

\section{Marketing}

Selling ethically

Practice promotion

\section{Administration \\ Office management systems \\ Basic financial management}

IT

Basic spreadsheet knowledge
The answer to this depends on the objectives, and in this scenario we can assume that the prime practice objective requiring immediate action is to increase the profitability of the practice. As the owner you have decided that you are going to expand the periodontal potential of the practice because there is very little periodontal emphasis in the other practices nearby and it fits in with your ultimate aim of creating a preventive practice rather than a restorative one.

Obviously marketing and practice promotion is important, but you can buy in expertise in this area rather than try and train your staff, so your priorities are:

1. To increase income as quickly as possible

2. To ensure a reputation for premium periodontal care is created

3. To delegate the financial running of the practice to the practice manager

Having made these decisions the training needs that take priority are obviously the need for your associate to feel confident in selling and to be able to provide excellent periodontal care, so the two areas of training need that become a priority are selling and periodontal monitoring. As far as the practice manager is concerned selling is also important (especially if you decide to get a consultant into the practice as it will cost the same to train both of them as one) but the priority areas are an understanding of basic financial management and the ability to run effective meetings.

Figure 3 shows the subjects you have selected (ideally in consultation with the people involved) and also the dates when you propose to arrange the training. As stated previously the dates may not be met exactly, but the point of putting them in the plan is that you now have something to aim for.

\section{Costs}

Budgeting is essential for any business, and dental organizations are no exception. Thus your 


\section{continuing professional development}

plan needs to contain estimates of costs in order to maintain control over the overall budget. At the planning stage you need to put the estimates of costs in. When the plan is complete you may find a need to go back and change some of the training, either to cut back (in the case of going over your budget) or to increase it (if you are below budget and want to put the surplus into more training in order to help you achieve more objectives).

Training is often seen as an expense rather than an investment. However, if the training is to ensure the people become more effective (in other words are more competent at doing their jobs) then how can it be a cost? The result of training should be a more effective use of resource, resulting in greater income and hopefully increased profits. Whether this happens or not is the subject of the next chapter - evaluation.

Figure 4 shows some estimates on costs for the training you have planned. Note that the cost of the external consultant is the same whether Caroline or Caroline and Claire are involved. You could split the cost between the two individuals in the plan, or follow the example in this article.

When you have completed the plan you will have a total budget for training for a 12-month period, and you can then adjust it accordingly.

One point to bear in mind is that the costs in this plan are direct costs only. We have not considered the indirect costs (such as the travelling expenses, loss of earnings or the need to provide a locum or temporary staff). If you really want to know the cost of training these should also be factored into your plan.

\section{The link to objectives}

Most people would stop planning at this stage, but a more effective training plan will ensure

\section{Fig. 3 The training activity for two members of a dental practice in the year $200 \mathrm{I}$}

with appropriate dates included

PRACTICE TRAINING PLAN

\begin{tabular}{|c|c|c|c|c|c|c|c|}
\hline Name & $\begin{array}{l}\text { Training } \\
\text { activity }\end{array}$ & Date & Cost & $\begin{array}{l}\text { Training } \\
\text { objective/desired } \\
\text { outcome }\end{array}$ & $\begin{array}{l}\text { Link with business } \\
\text { objective }\end{array}$ & $\begin{array}{l}\text { Outcome/ } \\
\text { evaluation }\end{array}$ & $\begin{array}{l}\text { Further action } \\
\text { needed? }\end{array}$ \\
\hline $\begin{array}{l}\text { CAROLINE } \\
\text { DRAYMORE }\end{array}$ & $\begin{array}{l}\text { Course on perio } \\
\text { monitoring } \\
\text { External consultant } \\
\text { on selling }\end{array}$ & $\begin{array}{l}\text { May } 2001 \\
\text { Nov 200I }\end{array}$ & & & & & \\
\hline $\begin{array}{l}\text { CLAIRE } \\
\text { HOLBROOK }\end{array}$ & $\begin{array}{l}\text { Coaching on running } \\
\text { effective meetings } \\
\text { External consultant } \\
\text { on selling } \\
\text { Course on financial } \\
\text { management }\end{array}$ & $\begin{array}{l}\text { Feb 200I } \\
\text { Nov 200I } \\
\text { June 200I }\end{array}$ & & & & & \\
\hline
\end{tabular}

(C) UMD Professional Ltd

\section{Fig. 4 The training activity for two members of a dental practice in the year $200 \mathrm{I}$ with appropriate dates included}

\section{PRACTICE TRAINING PLAN}

\begin{tabular}{|c|c|c|c|c|c|c|c|}
\hline Name & $\begin{array}{l}\text { Training } \\
\text { activity }\end{array}$ & Date & Cost & $\begin{array}{l}\text { Training } \\
\text { objective/desired } \\
\text { outcome }\end{array}$ & $\begin{array}{l}\text { Link with business } \\
\text { objective }\end{array}$ & $\begin{array}{l}\text { Outcome/ } \\
\text { evaluation }\end{array}$ & $\begin{array}{l}\text { Further action } \\
\text { needed? }\end{array}$ \\
\hline $\begin{array}{l}\text { CAROLINE } \\
\text { DRAYMORE }\end{array}$ & $\begin{array}{l}\text { Course on perio } \\
\text { monitoring } \\
\text { External consultant } \\
\text { on selling }\end{array}$ & $\begin{array}{l}\text { May } 2001 \\
\text { Nov } 2001\end{array}$ & $\begin{array}{r}£ 159 \\
£ 800\end{array}$ & & & & \\
\hline $\begin{array}{l}\text { CLAIRE } \\
\text { HOLBROOK }\end{array}$ & $\begin{array}{l}\text { Coaching on running } \\
\text { effective meetings } \\
\text { External consultant } \\
\text { on selling } \\
\text { Course on financial } \\
\text { management }\end{array}$ & $\begin{array}{l}\text { Feb 200I } \\
\text { Nov } 2001 \\
\text { June } 2001\end{array}$ & $\begin{array}{l}\text { N/A } \\
\text { N/A } \\
£ 200\end{array}$ & & & & \\
\hline
\end{tabular}




\section{Fig. 5 The training activity for two members of a dental practice in the year $200 \mathrm{I}$ with appropriate dates included}

\section{PRACTICE TRAINING PLAN}

\begin{tabular}{|c|c|c|c|c|c|c|c|}
\hline Name & $\begin{array}{l}\text { Training } \\
\text { activity }\end{array}$ & Date & Cost & $\begin{array}{l}\text { Training } \\
\text { objective/desired } \\
\text { outcome }\end{array}$ & $\begin{array}{l}\text { Link with business } \\
\text { objective }\end{array}$ & $\begin{array}{l}\text { Outcome/ } \\
\text { evaluation }\end{array}$ & $\begin{array}{l}\text { Further action } \\
\text { needed? }\end{array}$ \\
\hline $\begin{array}{l}\text { CAROLINE } \\
\text { DRAYMORE }\end{array}$ & $\begin{array}{l}\text { Course on perio } \\
\text { monitoring } \\
\text { External consultant } \\
\text { on selling }\end{array}$ & $\begin{array}{l}\text { May } 2001 \\
\text { Nov } 2001\end{array}$ & $\begin{array}{l}€ 159 \\
£ 800\end{array}$ & $\begin{array}{l}\text { Competent in monitoring } \\
\text { basic perio indices } \\
\text { Confidence in selling } \\
\text { ethically to more patients }\end{array}$ & $\begin{array}{l}\text { Create a preventive } \\
\text { practice } \\
\text { Increase profits } \\
\text { by } 20 \%\end{array}$ & & \\
\hline $\begin{array}{l}\text { CLAIRE } \\
\text { HOLBROOK }\end{array}$ & $\begin{array}{l}\text { Coaching on running } \\
\text { effective meetings } \\
\text { External consultant } \\
\text { on selling } \\
\text { Course on financial } \\
\text { management }\end{array}$ & $\begin{array}{l}\text { Feb 200I } \\
\text { Nov } 2001 \\
\text { June 200I }\end{array}$ & $\begin{array}{l}\text { N/A } \\
\text { N/A } \\
£ 200\end{array}$ & $\begin{array}{l}\text { Ability to run meetings } \\
\text { more effectively } \\
\text { Confidence and } \\
\text { competence in selling } \\
\text { Ability to understand basic } \\
\text { finances }\end{array}$ & $\begin{array}{l}\text { Increase profits } \\
\text { by } 20 \%\end{array}$ & & \\
\hline
\end{tabular}

that the training is both appropriate and evaluated. The first stage of this is to check the link with objectives.

First we need to ensure the training links to training objectives, or at least will ensure the desired outcome. If we have made the right decisions this can often appear obvious, resulting in the feeling 'Of course the training will achieve the objective', but it is also easy to sanction training that is inappropriate if we do not carry out this step.

For example, we may have a business objective of increasing the number of new patients who follow-up a consultation with treatment. At the same time we also want to attend a course on implants. In order to justify attending the course on implants we try to convince ourselves it is worth doing because it will attract new patients to the practice (thus achieving the business objective). Without the training objective we could easily spend the money on the course because we feel (wrongly) that the objective is being achieved.

However, if we really wanted to check if the training objective was being met we would need to set an objective of being confident and competent in providing implants. Secondly, we would need to be confident that the best way of increasing new patients was to become competent at implants. Providing the two are correct, then the course on implants would also be appropriate, but are they? Do we really want to convert the practice into one providing implants? If we do, is the best way to become competent ourselves or to advertise for a specialist? And is either of these choices the most cost-effective for increasing the number of new patients having treatment carried out?

The answer might well be 'yes', but the question needs to be asked and then considered carefully. If we have an aim of creating a preventive practice then this seems at odds with the idea of an implant practice, as this is obviously restorative. Perhaps the aim needs changing, or perhaps we have allowed a momentary lapse in our focus to divert us from our aim? Although we can obviously change our mind (after all it is our practice) is that what we really want or just a temporary diversion?

Checking that both the training objective and the business objective are being met because of the training helps to keep on focus, and also helps ensure the training is genuinely worth the cost in both time and money.

Figure 5 shows how the proposed training in our plan does fit in with our current training and business objectives.

\section{Conclusion}

At this stage the plan is not yet complete. That is because the two final columns are still blank. But we cannot evaluate the training until after it has been completed, nor can we assess if further action is needed until some time afterwards. Both of these steps will be considered in the next part of this series.

For this reason you may decide to leave them out of your training plan completely. The disadvantage of this is that it prevents you from being reminded to carry them out, which obviously means it is possible to carry out training and then not evaluate its efficacy. As we shall see in the next installment in the series this can be unwise, and is definitely not effective. 